\title{
School librarians' intellectual freedom attitudes and practices
}

\begin{tabular}{|r|l|}
\hline Journal: & New Library World \\
\hline Manuscript ID & NLW-01-2016-0002 \\
\hline Manuscript Type: & Article \\
\hline Keywords: & $\begin{array}{l}\text { censorship, school libraries, freedom of information, filtering, access to } \\
\text { information, labelling }\end{array}$ \\
\hline \multicolumn{2}{|l}{} \\
\hline
\end{tabular}



attitudes and practices

\author{
Introduction \\ The American Library Association (ALA) (n.d.) defines intellectual freedom as "the right of every \\ individual to both seek and receive information from all points of view without restriction. It \\ provides for free access to all expressions of ideas through which any and all sides of a question, \\ cause or movement may be explored. Intellectual freedom encompasses the freedom to hold, \\ receive and disseminate ideas". Such issues are ongoing concerns for all librarians, not least those \\ serving children and young people. The question of how to deal with controversial books; whether \\ and how Internet access should be controlled; and how to react to pressure from outside bodies \\ such as parents and community groups are all issues which children's and school librarians are \\ regularly required to make decisions about.
}

The importance of the role of librarians in promoting freedom of information has been stated on numerous occasions. For example, the International Federation of Library Associations and Institutions has asserted: "A commitment to intellectual freedom is a core responsibility of the library and information profession worldwide, expressed through codes of ethics and demonstrated through practice" (IFLA, 2002). According to CILIP (2005), access to information "should not be restricted on any grounds except that of the law. If publicly available material has not incurred legal penalties then it should not be excluded on moral, political, religious, racial or gender grounds, to satisfy the demands of sectional interest". Considering school libraries in particular, According to ALA (2008) "libraries should not limit the selection and development of library resources simply because minors will have access to them. Institutional self-censorship diminishes the credibility of the library in the community, and restricts access for all library users".

In practice, however, the position of librarians on this issue is often not as clear cut as such proclamations might suggest. For example, Marco $(1995$, p.15) argues that "librarians, as gatekeepers, are authorised censors of their societies, and censorship is a library responsibility rather than a library problem". Curry (1997) interviewed British and Canadian public library directors and discovered that some agreed with the provision of controversial material, citing the library's mission of provision of information, but others argued against provision of such material in order to protect individuals from harm, protect the social fabric and keep the library out of trouble with the local community and law. More recently, Brandon and Murray's (2007, p.3-4) Hate on the State report accused a number of UK public libraries of stocking "substantial quantities of literature preaching violent jihad" which they argue "risks radicalising Muslims while making non-Muslims more hostile towards the Islamic faith". Although the MLA (2008) responded by publishing guidance for libraries dealing with material of this nature, McMenemy (2008, p.344) criticised the "dangerous ambivalence" within the profession as a whole in reaction to the report, arguing that "the muted reaction to the issues raised in the report indicates something very wrong within the library profession in Great Britain".

\title{
Censorship research in libraries
}

Censorship and freedom of information issues have been the subject of relatively limited research in the information studies field. That which has been conducted suggests that librarians are often not the vigorous advocates of intellectual freedom suggested by proclamations from professional bodies. There is frequently a noticeable divide between principles and practice. Furthermore, selfcensorship has been reported as an ongoing issue within the profession; Huston (2004, p.242) 
describes a book selection process that forgoes buying books that might be challenged as "silent censorship". As Moody (2004) notes, it is often easy to justify censorship under the veil of literary quality, lack of funding or insufficient demand.

In one of the earliest studies of librarians' attitudes towards censorship and freedom of information, Fiske (1959) investigated school and public librarians in California. She discovered that, in many cases, librarians were actually the most active censors of their own libraries; they were highly selective in the titles purchased, minimising controversial material to avoid the possibility of complaints.

In the 1960s, Busha (1972) carried out a study of the attitudes of public librarians in the United States. He surveyed 900 randomly selected public librarians and concluded that, while these librarians did not hesitate to express agreement with the principles of intellectual freedom, many apparently did not feel strong enough as professionals to assert these principles in the face of real, or anticipated, censorship pressures. McDonald (1993) adapted this survey for US school librarians and her findings reaffirmed the gap between professional beliefs and practices.

Curry (2001) performed a quantitative analysis of the placement of controversial children's fiction books in public libraries in British Columbia in Canada. She found that around $15 \%$ of the copies of controversial young adult titles had been placed in adult fiction areas, and noted that books containing sexual material were more likely to be moved. In a survey of library OPACs, Coley (2002) found $82 \%$ of high schools investigated engaged in self-censorship and suggested that smaller libraries tended to be more conservative and least likely to own controversial books. Hughes-Hassell et al (2013) found that, among school libraries in Southern US states, LGBTQ-themed titles were being under-collected. This suggests, as Oppenheim and Smith (2004, p.159) note, "librarians have been as irrational and discriminatory as other censors and at times for the same uncomfortable reason: personal taste".

\section{Reasons for censorship}

Many studies have therefore indicated a discrepancy between intellectual freedom beliefs and librarians' practice, especially in the ways in which they exercise self-censorship. Although the topics and types of resources considered controversial may have changed over time, it appears that the conflict between theory and practice has not. A number of reasons have been suggested to try to explain this. Conflict between a personal belief system and resource content has been suggested by many as a reason for self-censorship decisions. In addition, it is argued that community opinion often contributes to this behaviour (Callison 1990). In the case of school librarians in particular, Hopkins (1992) hypothesises that they suffer from low self-esteem, which affects professional practice and confidence in making censorship decisions. Dillon and Williams (1994) found school librarians often choose censorship as a response to societal threats presented in literature to protect the reader from the content, or to protect content from being questioned. They describe selfcensorship as a "-secret practice [that is] the least obvious but arguably most powerful and pervasive form of censorship which is informal, private, and originates with the decision maker" (p.11).

Despite occasional high profile cases, challenges to library resources, in UK public library sector at least, appear to be relatively rare. In a survey of Scottish public library authorities, Taylor and McMenemy (2013) reported just three challenges to books per year on average for the whole country; $68 \%$ of local authorities had received no complaints in the previous five years. However, children and young people's titles did account for nine of the fifteen complaints detailed. Arguably this may mean that school librarians are likely to face more challenges. Hopkins (1991) found that one third of schools experienced at least one challenge and Adler's (1993) research in California found that $40 \%$ of schools were disrupted by challenges to curricular materials. Nevertheless, it is 
important not to exaggerate the problem as recent figures show that, in the United States at least, school libraries were not involved in the majority of censorship challenges. The ALA's (2014) Office of Intellectual Freedom reported that only 11\% of book challenges in 2014 involved school libraries compared to $38 \%$ involving public libraries and $36 \%$ involving schools (other than their libraries).

\section{Methodology}

In 2004, a survey of school and children's librarians in the UK was conducted (Author, 2005), following a format similar to that use by McDonald (1993) and Busha (1972). The findings reiterated the fact that librarians were more likely to subscribe to the principles of intellectual freedom than to carry out practical actions to combat censorship, but found only limited links between any demographic factors measured and attitudes towards intellectual freedom. The survey reported below repeats the 2004 survey a decade on to explore whether attitudes have altered in the intervening period and to investigate the most significant censorship issues facing school librarians today.

The questionnaire used for both the 2004 and 2015 surveys was based on that devised by McDonald (1993) in the United States the 1980s, which in turn had been based in Busha's (1972) survey of public library staff in the 1960 s. McDonald had adapted the earlier survey to make it appropriate for school libraries and to bring it up to date. A similar process was undertaken for the UK survey conducted in 2004; McDonald's survey was used as a basis, but was adapted to make it applicable to the UK and to school and children's librarians in the twenty-first century. For example, questions referring to the Internet were added and references to specific US publications removed. In 2015, the 2004 survey was repeated with only minor changes to clarify phrases that feedback on the previous survey had indicated may be unclear.

SurveyMonkey was used for the 2015 survey, which was distributed electronically via email lists (e.g. SCHOOL-LIBRRAIES-RESEARCH JISCMAIL list; SLN Yahoo group list), blogs and websites including the School Library Association ${ }^{1}$ and Heart of the School ${ }^{2}$. In addition, individual emails were sent to all Schools Library Services listed by the SLA ${ }^{3}$. The survey remained open between $20^{\text {th }}$ September and $31^{\text {st }}$ October 2015. It is, of course, acknowledged that the majority of those responding via these methods are likely to have an interest in the subject area and may have a greater awareness of some of the issues than a random sample of the whole profession, but given the patchy nature of UK school library provision, the latter would be impossible to achieve. A further problem in carrying out this type of research is the danger that respondents will give what they think are the 'right' answers rather than the truthful ones. To try to avoid this, similar strategies to those adopted by McDonald, and previously Busha, were used, in particular phrasing questions so that restrictive practice were projected on to others (e.g. referring to school/children's librarians in general, rather than 'you') as well as the use of a five-point likert scale to allow greater discrimination than simple 'yes/no' answers.

The survey included two types of question:

- Questions relating to attitudes towards intellectual freedom principles (9 questions)

- Questions assessing attitudes towards the practical application of these principles in libraries (18 questions).

Further the questions can be divided into four categories:

- Policy-related issues

- Diversity of collections

${ }^{1}$ http://www.sla.org.uk/blog.php

2 http://heartoftheschool.edublogs.org/

3 http://www.sla.org.uk/schools library $\sim$ services uk.php 
- Access to resources

- Selection of resources.

At the analysis stage, the categories of strongly agree, agree, uncertain, disagree and strongly disagree were converted into scores from 1 to 5 , with 1 indicating restrictive practices and 5 support for greater freedom. Analysis of variance (ANOVA) was used to investigate relationships between attitudes towards intellectual freedom and censorship, and variables such as age, gender, experience, membership of professional organisations and education. In the analysis of the relationship between attitudes towards intellectual freedom and its practical application, Student's t-test (matched pairs) was used.

There were 96 responses; 93 (96.9\%) from librarians working in schools; two from SLS librarians; and one from a public librarian. $88.5 \%$ respondents were women and $11.5 \%$ were men. There were more responses from among the older age groups; more than $40 \%$ were over 50 , compared to just $11 \%$ aged 30 or under. Around one-third had five years' experience or less working as a school or children's librarian, while just over one-quarter had at least 15 years' experience. The majority (88.5\%) had a degree-level qualification or higher.

$81.2 \%$ of respondents were members of at least one professional association. $57.3 \%$ were members of CILIP and $72.9 \%$ were members of the School Library Association. Small numbers indicated they were also members of regional or local support groups for librarians. The majority of respondents supported secondary school students: $88.5 \%$ said they worked with Key Stage 3; 82.3\% with Key Stage 4; and $76.0 \%$ with Key Stage 5 . Smaller numbers supported younger students: $20.8 \%$ worked with Key Stage 2; $13.5 \%$ with Key Stage 1; and 10.4\% with pre-school children.

The most notable difference between this sample and those responding in 2004 is that, in 2015, almost all were working in school libraries; school librarians formed just one-quarter of the sample in 2004. This difference is likely to be partly due to differences in the way in which information about the survey was distributed, but is also likely to be due to wider changes in public library authorities as the number of children's librarians and schools library service librarians have both declined noticeably during the last decade. In 2012, CILP reported that only $62 \%$ of authorities in England and Wales responding to its survey had a SLS and in half of these the service was being reviewed, with closure being a possibility in a quarter of cases. Furthermore, $60 \%$ of public library authorities were planning to reduce staff ( $80 \%$ had done so the previous year) (CILIP, 2012). It is important to take this important difference into account when comparing findings from the two surveys.

\section{Findings}

Overall, respondents' average scores for intellectual freedom statements were higher than that for practical application statements, meaning they were more likely to express support for intellectual freedom in theory than in practice; on average, scores were 0.7 points higher. A matched pairs t-test found a significant difference between the two sets of scores $(p<0.01)$, indicating inconsistences between the two measures. This was unsurprising given that previous research has reported that, in most cases, librarians are likely to hold more liberal intellectual freedom views in theory than are demonstrated through their actions.

Table 1 below shows individual questions where the strongest pro-intellectual freedom, and strongest pro-censorship, attitudes were evident.

Table 1 here 
Comparing the statements in both columns of the table, the language used appears to have had an influence. Statements containing obviously negative words such as 'remove' or 'exclude', for the most part, prompted pro-intellectual freedom reactions. Equally, explicitly positive phrases, such as 'choose freely', 'enrich' and 'widest diversity' resulted in pro-intellectual freedom responses. Procensorship reactions were sometimes evident, however, in response to some of the subtly-worded statements.

It is noteworthy that some statements in the two columns are remarkably similar. For example, 96.9\% agreed with the theoretical statement, "Young people should have the freedom to read and consider a wider range of ideas than those that may be held by the majority in their local community". However, when a similar idea was presented as a more concrete example, "Parents should be able to expect that resources in the public/school library will not undermine commonly held values", more pro-censorship attitudes were evident as $27.0 \%$ agreed with this. A similar pattern was also evident in the two comparable statements: "School/children's librarians should resist the efforts of individuals or groups seeking to impose their views on the management and running of the library" ( $85.5 \%$ agreed) and "If the head teacher or a local councillor requests that a book or other resource be removed from the library, the librarian should remove the resource" (29.1\% agreed). In particular, it would appear that the introduction of specific actors, such as parents or head teachers, weakened some librarians' commitment to intellectual freedom principles.

Two of the statements that prompted the strongest pro-censorship responses related to access issues, namely, labelling and filtering. 37.5\% of respondents agreed that "Books and other resources about controversial subjects should be clearly labelled as a guide for young people, parents and teachers who wish to avoid works of this type"; only $29.1 \%$ disagreed with this statement. The same statement prompted a less strong pro-censorship response in the 2004 survey of school, public and SLS librarians, when $24.9 \%$ agreed and $48.5 \%$ disagreed. With regard to filtering, more than half of the 2015 respondents (57.3\%) agreed that "School/children's librarians should ensure that access to controversial websites is restricted by filtering software or other methods"; only $9.4 \%$ disagreed. However, it is worth noting that the percentage agreeing had been even higher in the 2004 sample at $72.2 \%$, while the percentage disagreeing was approximately the same.

While some access-related issues therefore appeared to present challenges for school librarians' commitment to intellectual freedom, none of the statements relating to diversity prompted a significant number of pro-censorship responses. As in the 2004 survey, it appears that this is an area where intellectual freedom is less controversial within the profession.

Another issue worthy of note is that responses to two of the statements indicate that a number of librarians place significant emphasis on their personal ability, or right, to determine whether or not resources are included in the collection. Around one-quarter agreed with the statements: "School/children's librarians are in a position to recognise dangerous or controversial ideas in books or other resources and should ensure their availability is carefully controlled" (23.9\% agreed); and "The school/children librarian's moral, literary and aesthetic values should be the standard for determining what materials should be included in the library collection" (27.1\% agreed). Again, there was some differences between these results and the 2004 survey in which $49.7 \%$ agreed with the former statement, but only $13.0 \%$ agreed with the latter.

\section{Censorship, intellectual freedom and demographic characteristics}

No significant differences were found for either freedom of information or practical application scores based on respondents': gender, age, years of experience; or level of education. However, there was some evidence of a difference in practical application scores (but not intellectual freedom scores) depending on whether librarians worked with pre-school children or were members of professional associations, as shown in Table 2 . Those who worked with very young children were, 
perhaps unsurprisingly, most likely to censor. On the other hand, those who were members of professional associations were least likely to.

Table 2 here

Focusing on each of the four categories of questions (policy, access, diversity and selection), there were no significant differences in responses to selection or access-related questions by any of the demographic characteristics. There was some evidence that the age groups librarians worked with and their gender impacted on their attitudes towards diversity as shown in Table 3. Again, those working with the youngest age group were most likely to be in favour of limiting diversity of resources, while those supporting the oldest age group were most likely to support diversity. Although the number of male librarians in the sample was small, there is evidence that they were more likely to be in favour of promoting diversity of resources compared to their female counterparts.

Table 3 here

In the case of policy-related questions, there was some evidence of a difference depending on whether or not librarians were members of a professional association, with those who were members of associations having more pro-intellectual freedom scores, as shown in Table 4. This suggests that, as might be hoped, membership of professional bodies may provide librarians with support in implementing and upholding pro-intellectual freedom policies.

\section{Table 4 here}

\section{Discussion}

Busha (1972) found that most public librarians would state principles of intellectual freedom, but were not strong enough as professionals to assert these in the face of real or anticipated censorship pressures. Based on the findings reported above, the same would appear to be true of UK school librarians. The potential for controversy seemed to be a concern; librarians were often unsure how they should react to pressure from parents, headteachers and other groups to exclude, or limit access to, resources. It might be hypothesised that librarians in school libraries are more isolated than those in public libraries and schools library services, so feel less able to assert their beliefs regarding intellectual freedom. There was most consistency between theory and practice when it came to diversity of resources provided (i.e. providing children and young people a range of viewpoints). None of the diversity statements prompted strongly pro-censorship responses. As in the 2004 survey (Author, 2005), it appears that this is an area where intellectual freedom is less controversial within the profession. Conversely, in issues relating to selection, policy and in particular access to controversial resources, librarians were likely to express support for the idea of intellectual freedom, but to be restrictive in practice.

Less than one-third of respondents disagreed with the statement "Books and other resources about controversial subjects should be clearly labelled as a guide for young people, parents and teachers who wish to avoid works of this type". This directly contradicts ALA (2005) guidance that "opposes labeling as a means of predisposing people's attitudes toward library materials". As this guidance acknowledges, labelling can be an appropriate way to guide users to potentially useful resources, but this is very different to the use of labels to restrict or discourage access to materials. Although, as in many aspects of intellectual freedom, UK professional bodies have not taken such a robust stance as their American counterparts, the specific question of age-related labelling books has been the subject of controversy in the UK in recent years with the 'No to Age Banding' campaign being 
supported by CILIP (2008) among others. This is clearly one area where many school librarians struggle to put intellectual freedom principles into practice and the reasons for, and implications of, this are worthy of further study.

In addition, less than $10 \%$ of respondents did not agree with internet filtering or similar restrictions. While the various arguments for and against internet filtering are beyond the scope of this paper, in an intellectual freedom context, as CILIP's Policy Officer argues, "blocking or over-zealous filtering of the internet is not an effective way to raise awareness and empower people to make their own independent judgements about material they are inevitably going to encounter at some point in their lives" (May, 2014). This document further points out that filtering promotes a false sense of security and denies parents and carers (and equally school librarians) the opportunity to engage with children about their proper use of the internet. May (2014) argues that filtering "does little to teach resilience and engender the confidence to engage with the internet". However, the findings of this survey suggest that internet filtering is widely accepted amongst UK school librarians. Such attitudes run the danger of negating the value of school librarian's professional role with regard to supporting and promoting the effective use of online information in ways that offer more sophisticated alternatives to automated control.

Pro-censorship attitudes were also displaying in relation to stock selection statements in the questionnaire. This can be a complex issue as the distinction between selection and censorship can often become blurred. Asheim (in Froehlich, 2000) argues, "Selection....begins with a presumption in favour of liberty; censorship with a presumption in favour of thought control". It was noteworthy that $20.8 \%$ of respondents believed that school/children's librarians should exclude materials because of the origin, background or views of the authors or creators. This is more than double the percentage agreeing with the same statement in the 2004 survey, and directly contradicts one of the articles of the Library Bill of Rights (ALA, 1996). While of course this only covers libraries in the United States, it is worrying that one-fifths of UK librarians in this sample adopted this view. This perhaps reflects growing concerns about extreme materials and reactions to commentary such as the Hate on the State report (Brandon and Murray, 2007).

Another issue is that a number of librarians placed significant emphasis on their personal ability, and right, to determine whether resources are included in the school library collection. To an extent, this is understandable as they are employed as experts in information, but this emphasis on the individual's judgement, especially of what is 'controversial' or 'moral', leaves librarians worryingly open to challenges from groups or individuals wishing to impose their views on the running of the library. This is where professional associations take play an important role if they provide guidance that takes the emphasis away from the individual and towards more general (and widely endorsed) policies or principles, while retaining the value of individual judgement in the specific setting of each individual school library. As the MLA $(2008$, p.9) says in the case of public libraries, "Stock should be selected objectively according to the Collection Development Policy, not determined by the personal view of library staff, suppliers or other partners.". Similarly, Oppenheimer and Smith (2004, p.164) argue, "a better way to protect against censorship is the use of a collection management policy". As well as providing a firm base from which to defend selection decisions, this can protect again "personal bias or even personal whim" (Harer and Harris, 1994, p.26).

Several previous studies suggested there may be links between librarians' attitudes towards censorship and various demographic characteristics such as educational level or experience (e.g. Busha, 1972; McDonald, 1993; Pope, 1974). However, the often-contradictory findings from different studies indicate that identifying clear, universal factors likely to affect attitudes towards intellectual freedom is far from straightforward. In this research, few factors were found to be statistically significant among the sample of UK school librarians studied in 2015. However, 
membership of professional organisations was a factor that did appear relevant. There was evidence that membership of professional associations is linked to higher practical application and policyrelated scores, suggesting the professional associations may have an important role in supporting librarians in this area through information and awareness-raising, or through direct or peer support. UK professional associations could perhaps take on a stronger leadership role to provide greater support for librarians, especially those working in more isolated settings such as school libraries. As Oppenheim and Smith (2004, p.168) point out, "The ALA has undoubtedly always been more audible, visible and active in its handling of censorship issues than CILIP...In comparison, CILIP has been quiet, unobtrusive and passive". In previous studies, McDonald (1993) had found that membership of state and national professional organisations contributed significantly to scores for both intellectual freedom and its practical application. This suggests that the role of professional bodies may be worthy of further research.

Although this is based on a small sample, there was some evidence that male librarians may have more liberal attitudes towards diversity issues. This concurs with other surveys: both Busha (1972) and Pope (1974) had found the female librarians were more likely to practice censorship than their male counterparts. The age group supported also, perhaps unsurprising, appeared to have an impact on attitudes towards censorship. Those working with young children displayed more caution, while those working with those on the cusp of adulthood tended to support intellectual freedom more strongly. It may be the case that those working with very young children would benefit from more guidance about how meet the particular challenges of implementing intellectual freedom principles effectively with this age group. Again, this topic would benefit from further research.

\section{Conclusion}

As Oppenheim and Smith (2004, p.163) point out, "resolving an ethical issue in theory is far simpler than when applying it in a practical situation". This research concurs with that conducted previously in finding that librarians' censorship practices are not solely determined by their theoretical attitudes towards intellectual freedom. The findings suggest that while school librarians hold strong pro-intellectual freedom views, they may need additional support to put these into practice. School librarians are undoubtedly in a challenging position; they are often solo workers and need to find ways to uphold professional intellectual freedom principles within a school setting. In doing so, they need to balance the responsibility for ensuring young people's safety with the need to support their intellectual development and present challenges that will prepare students for life after school. As young adult author Cynthia Grant (1990, p. 50) suggests, "the best collection is one that always makes you feel slightly uneasy". School library collections should be challenging; they should raise, expose and promote debate, rather than ignoring or silencing it.

\section{References}

Adler, L. (1993), "Curriculum challenges in California", Record in Educational Administration \& Supervision 13(2), pp.10-20.

ALA (nd), Intellectual Freedom and Censorship Q \& A, http://www.ala.org/advocacy/intfreedom/censorshipfirstamendmentissues/ifcensorshipqanda (accessed 11 January 2016).

ALA (nd), Censorship in Schools, http://www.ala.org/advocacy/intfreedom/censorshipfirstamendmentissues/censorshipschools, (accessed 11 January 2016). 
ALA (2014), 2014 Book Challenges Infographic http://www.ala.org/news/state-americas-librariesreport-2015/2014-book-challenges-infographic (accessed 11 January 2016).

ALA (2008), Free Access to Libraries for Minors: An Interpretation of the Library Bill of Rights, http://www.ala.org/Template.cfm?Section=interpretations\&Template=/ContentManagement/Conte ntDisplay.cfm\&ContentID=8639 (accessed 11 January 2016).

ALA (2005), Labels and Rating Systems: An Interpretation of the Library Bill of Rights, http://www.ala.org/Template.cfm?Section=interpretations\&Template=/ContentManagement/Conte ntDisplay.cfm\&ContentID=8657 (accessed 11 January 2016).

ALA (1996), Library Bill of Rights, http://www.ala.org/advocacy/intfreedom/librarybill (accessed 11 January 2016).

Brandon, J. and Murray, D. (2008) Hate on the State: how British libraries encourage Islamic extremism, http://henryjacksonsociety.org/wp-content/uploads/2013/01/hate-on-the-state.pdf (accessed 11 January 2016).

Busha, A. (1972), Freedom Versus Suppression and Censorship, Colorado: Libraries Unlimited.

Callison, D. (1990), "A Review of the research related to school library media collections: Part I", School Library Media Quarterly 19(1), pp.57-62.

Coley, K. (2002), "Moving towards a method to test for self-censorship by school library media specialists2, School Library Media Research 5, http://www.ala.org/aasl/sites/ala.org.aasl/files/content/aas/pubsandjournals/slr/vol5/SLMR Testfor SelfCensorship V5.pdf (accessed 11 January 2016).

CILIP (2012), A Changing Landscape: a survey of public library authorities in England, Wales and Northern Ireland 2012-13, http://www.cilip.org.uk/sites/default/files/documents/CILIP Public Library Survey Summary Repo rt A Changing Landscape 2012-13 0.pdf (accessed 11 January 2016).

CILIP (2008) CILIP has issued the following statement of support for the 'No to Age Banding' Campaign, http://www.cilip.org.uk/sites/default/files/documents/2008 No\%20to\%20age\%20banding\%20supp ort\%20statement.pdf (accessed 11 January 2016).

CILIP (2005), Intellectual Freedom, Access to Information and Censorship, http://www.cilip.org.uk/sites/default/files/documents/2005_foistatement0705.pdf (accessed 11 January 2016).

Curry, A. (1997), The Limits of Tolerance: Censorship and Intellectual Freedom in Public Libraries, London: Scarecrow Press.

Curry, A. (2001), "Where is Judy Blume? Controversial Fiction for Older Children and Young Adults". Journal of Youth Services in Libraries, 14 (3), pp.28-37.

Dillon, K. and C. L. Williams (1994), "Censorship, children, and school libraries in Australia: issues of concern", Emergency Librarian 22(2), pp.8-14. 
Fiske, M. (1959), Book selection and Censorship: A Study of School and Public Libraries in California, Berkeley, CA: University of California Press.

Froehlich, T.J. (2000), Intellectual freedom, ethical deliberation and codes of ethics, IFLA Journal 26, pp. 264-71.

Harer JB and Harris S. (1994), Censorship of Expression in the 1980s: a Statistical

Survey. London: Greenwood Press .

Grant, Cynthia. 1995. "Tales from a YA author: slightly uneasy", School Library Journal 41, pp. 48-50.

Hopkins, D.M (1992), "Perspectives of secondary library media specialists about material challenges", School Library Media Quarterly 21(4), pp.15-24.

Hopkins, D.M. (1991), Challenges to materials in secondary school library media centers: Results of a national study. Journal of Youth Services in Libraries 4(2), pp.131-40.

Hughes-Hassell, S., Overburg, E. and Harris, S. (2013) Lesbian, Gay, Bisexual, Transgender, and Questioning (LGBTQ)-Themed Literature for Teens: are school libraries providing adequate collections? School Library Research, 16,

http://www.ala.org/aasl/sites/ala.org.aasl/files/content/aas/pubsandjournals/slr/vol16/SLR LGBTQT hemedLiteratureforTeens V16.pdf (accessed 11 January 2016).

Huston, K. (2004), Silent censorship: the school library and the insidious book censor, 72 UMKC Law Review 241, pp. 241-55.

IFLA (2002), Glasgow Declaration on Libraries, Information Services and Intellectual Freedom, Glasgow: IFLA.

Marco, G. (1995) Two false dogmas of censorship, New Library World 96(7), pp. 15-19.

May, J. (2014) Is web filtering in the UK excessive?, http://www.cilip.org.uk/blog/web-filtering-ukexcessive (accessed 11 January 2016).

McDonald, F.B. (1993), A Survey of School Librarians' Attitudes and Moral Reasoning, London: Scarecrow Press

McMenemy, D. (2008), Selection and censorship: librarians and their collections, Library Review 57(5), pp. 341-44.

MLA (2008), Guidance on the Management of Controversial Material in Public Libraries. London: Museums, Libraries and Archives Council.

Moody K (2004), Censorship by Queensland public librarians: philosophy and practice. Australasian Public Libraries and Information Services 17(4), pp.168-185.

Pope, M. J. (1974), Sex and the Undecided Librarian: a study of librarians' opinions on sexually oriented literature. Metuchen, N.J.: Scarecrow.

Taylor, K. and McMenemy, D. (2013), Censorship challenges to books in Scottish public libraries, Journal of Librarianship and Information Science 45(2), pp. 153-167. 
Tables

Pro-intellectual freedom attitudes displayed by Pro-censorship attitudes displayed by $>\mathbf{2 0} \%$ of $>95 \%$ of respondents respondents

PRACTICAL APPLICATION STATEMENTS

School/children's librarians should concentrate on building on collections of resources which directly support the curriculum rather than works of fiction dealing with social, psychological or sexual problems young people face.

(selection)

Some issues, such as homosexuality or drug taking, are too controversial for a children's/school library. (selection)

The school/children librarian's moral, literary and aesthetic values should be the standard for determining what materials should be included in the library collection. (selection)

Young people need to have access to a variety of resources to help them to develop critical thinking skills. (diversity)

School/children's librarians should remove, or prevent access to, resources which are known to have been the subject of censorship controversies in other schools/libraries. (access) School/children's librarians should not allow access to resources which portray the government in an unfavourable light. (selection)

School/children's librarians should take care to ensure that materials containing controversial views are excluded from school/children's library collections. (diversity)

\section{INTELLECTUAL FREEDOM STATEMENTS}

School/children's librarians should not exclude materials because of the origin, background or views of the authors or creators. (selection) If the head teacher or a local councillor requests that a book or other resource be removed from the library, the librarian should remove the resource. (policy)

Parents should be able to expect that resources in the public/school library will not undermine commonly held values. (selection)

Books and other resources about controversial subjects should be clearly labelled as a guide for young people, parents and teachers who wish to avoid works of this type. (access) School/children's librarians should ensure that access to controversial websites is restricted by filtering software or other methods. (access)

School/children's librarians are in a position to recognise dangerous or controversial ideas in books or other resources and should ensure their availability is carefully controlled. (access)

School/children's librarians should provide resources presenting a variety of points of view on current and historic issues. (selection) Young people should have the freedom to read and consider a wider range of ideas than those that may be held by the majority in their local community. (access)

School/children's librarians should resist the efforts of individuals or groups seeking to impose their views on the management and running of the library. (policy) School/children's librarians should be vigorous advocates of intellectual freedom. (policy) It is the responsibility of school/children's librarians to provide resources which enrich 
young people's quality of thought and

expression. (selection)

School/children's librarians should make it

possible for young people to choose freely from

a variety of points of view on controversial

subjects. (access)

School/children's librarians need not endorse

every idea in the resources they make available.

(diversity)

School/children's librarians should make

available the widest diversity of views and

expressions, including those which are

unpopular with the majority. (diversity)

Table 1: Statements prompting the strongest expressions of pro-intellectual freedom and pro-

censorship views

\begin{tabular}{|l|l|l|}
\hline Characteristic & $\begin{array}{l}\text { Average practical application } \\
\text { score (out of 5) }\end{array}$ & $\begin{array}{l}\text { ANOVA p } \\
\text { value }\end{array}$ \\
\hline Work with pre-school children & 3.34 & $\mathrm{p}=0.025$ \\
\hline Do not work with pre-school children & 3.68 & \\
\hline Member of a professional association & 3.71 & $\mathrm{p}=0.023$ \\
\hline Not a member of a professional association & 3.42 & \\
\hline
\end{tabular}

Table 2: Statistically significant differences in practical application scores

\begin{tabular}{|l|l|l|}
\hline Characteristic & Average diversity score & P value \\
\hline Work with pre-school children & 3.89 & $\mathrm{p}=0.012$ \\
\hline Do not work with pre-school children & 4.24 & \\
\hline Work with KS5 & 4.27 & $\mathrm{p}=0.016$ \\
\hline Do not work with KS5 & 4.16 & \\
\hline Female & 4.16 & $\mathrm{p}=0.005$ \\
\hline Male & 4.55 & \\
\hline
\end{tabular}

Table 3: Statistically significant differences in diversity scores

\begin{tabular}{|l|l|l|}
\hline Characteristic & Average policy score & P value \\
\hline Member of a professional association & 3.93 & $\mathrm{p}=0.049$ \\
\hline Not a member of a professional association & 3.63 & \\
\hline
\end{tabular}

Table 4: Statistically significant differences in policy scores 